J. Clin. Chem. Clin. Biochem.

Vol. 17, 1979, pp. 315-320

\title{
Evaluation of the Manual Enzyme Immunoassay (EMIT) Procedure for Determination of Serum Thyroxine
}

\author{
By T. A. Plomp, R. H. Drost, J. H. H. Thyssen, P. J. der Kinderen and R. A. A. Maes \\ Centre for Human Toxicology, University of Utrecht \\ and \\ Department of Endocrinology of the University of Utrecht, Academic Hospital, Utrecht, The Netherlands
}

(Received September 14, 1978/January 29, 1979)

\begin{abstract}
Summary: Our experience with the determination of thyroxine $\left(\mathrm{T}_{4}\right)$ in serum using a homogeneous enzyme immunoassay technique (EMIT, Syva Corp.) is reported. The intra-assay precision of the EMIT Manual Thyroxine Assay was investigated with 2 different calibrator concentrations and showed coefficients of variation varying from $5-2 \%$ for thyroxine concentrations of 40 and $120 \mu \mathrm{g} / 1$ thyroxine respectively. The inter-assay precision was investigated with different series of calibrators and serum specimens. Coefficients of variation for the calibrators varied from $35-5 \%$ in the range of $20-200 \mu \mathrm{g} / 1$ thyroxine and for the serum specimens in the range of $8-232 \mu \mathrm{g} / 1$ thyroxine from $50-4 \%$. The recovery of various amounts of thyroxine added to thyroxine-free serum varied between $91-103 \%$. The cross reactivity of structurally related compounds such as: monoiodothyronine, diiodothyronine, triiodothyronine, triiodothyroacetic acid and tetraiodothyroacetic acid was investigated.
\end{abstract}

Serum samples of 100 patients were analysed by EMIT and radioimmunoassay ( $\mathrm{T}_{4}$ RIA (PEG), Abbott Lab.). A good correlation was found between the EMIT and RIA assay $(r=0.96$, slope $=0.96$ and $y$-intercept $=3.37 \mu \mathrm{g} / \mathrm{l})$.

\section{Evaluation eines manuellen Enzymimmunassay (EMIT) für die Bestimmung von Thyroxin im Serum}

Zusammenfassung: Wir berichten über unsere Erfahrungen mit einem homogenen Enzymimmunoassay (EMIT, Syva Corp.) zur Bestimmung von Thyroxin im Serum. Die Präzision in der Serie wurde für die manuelle EMIT-Methode mit zwei Kalibratorkonzentrationen untersucht und ergab Variationskoeffizienten von 5-2\% für Thyroxinkonzentrationen von 40 und $120 \mu \mathrm{g} / 1$. Die Präzision von Tag zu Tag wurde mit verschiedenen Serien von Kalibratoren und Serumproben untersucht; es ergaben sich Väriationskoeffizienten von $35-5 \%$ im Bereich von $20-200 \mu \mathrm{g} / 1 \mathrm{Kali}$ brierlösung und von 50-4\% für Serumproben im Bereich von 8-232 $\mu \mathrm{g} / 1$ Thyroxin. Die Wiederfindung verschiedener Mengen Thyroxin, die thyroxinfreiem Serum zugesetzt wurden, schwankte zwischen 91 und 103\%. Die Kreuzreaktivität strukturell verwandter Verbindungen wie Mono-, Di- und Triiodthyronin sowie Tri- und Tetraiodthyroessigsäure wurde untersucht.

Serumproben von 100 Patienten wurden mit der EMIT-Methode und einem Radioimmunassay ( $\mathrm{T}_{4} \mathrm{RIA}$ (PEG), Abbott Lab.) untersucht. Es fand sich eine gute Korrelation zwischen Enzym- und Radioimmunassay $(r=0,96$; Steigung $=0,96$ und $y$-Intercept $=3,37 \mu \mathrm{g} / \mathrm{l}$ ).

\section{Intrôduction}

The competitive protein binding assay described by Murphy \& Pattee has provided the basis of many method's subsequently developed for the measurement of thyroxine $\left(\mathrm{T}_{4}\right)$ in serum (1). The principle of their procedure was based on the competition between radiolabeled $\mathrm{T}_{4}$ and serum $\mathrm{T}_{4}$ for binding sites on thyroxine binding globulin.
Their method allowed the direct quantitation of $T_{4}$ without interferences from organic or inorganic iodides. This test, however, requires an initial extraction of thyroxine from serum proteins. The variation in the recovery of thyroxine during this procedure greatly affects accuracy and precision of the results (2). The development of a radioimmunoassay (RIA) for $\mathrm{T}_{4}$ has resulted in a strong increase in sensitivity and 
specificity for the thyroxine determinations in serum $(3,4,5)$. By using antibodies specific to thyroxine, the $T_{4}$ radioimmunoassay method eliminated many of the interference problems associated with the competitive protein binding assay, thus improving the reliability of the test. Like competitive protein binding assay methods, however, the $\mathrm{T}_{4}$ radioimmunoassay used radioactive components which have the disadvantages inherent to all radioisotopic methods when used in the routine clinical laboratory: special isotopic safety considerations, licensure requirements, decay of radiolabeled reagents, need for radiocounting equipment and in the method itself, the obligatory separation of antibody bound from unbound isotope. In 1975, Ullman et al. reported the development of an enzyme-multiplied immunoassay technique (EMIT) ${ }^{1}$ ) for thyroxine, which could simultaneously eliminate all the above outlined disadvantages without sacrifice of the speed, specificity and sensitivity previously characteristic only of the radioimmunological methods (6). The EMIT enzyme immunoassay for thyroxine used stable enzyme labels instead of radioisotopic labels. When the enzyme is activated, the chemical reaction that occurs can be monitored spectrophotometrically and since the enzymatic activity is inversely related to the total concentration of $T_{4}$ in the sample, quantitation of the total $\mathrm{T}_{4}$ in serum can easily be performed. Furthermore, unlike radioimmunoassay procedures, the enzyme immunoassay for thyroxine is homogeneous and no separation step is required.

The procedure is straight forward and lends itself well to automation $(6,7)$. Recently automated procedures for the determination of $\mathrm{T}_{4}$ by EMIT on the AGA Autochemist (LKB, Bromma, Sweden) and the ABA-100 (Abbott, South Pasedena, California) have been reported $(8,9,10)$. These automated EMIT thyroxine assays yielded results that agreed well with those obtained by a radioimmunoassay and are, according to the investigators, good alternatives to the commonly used RIA procedures. Until now, no study has been published on the evaluation of the EMIT Manual Thyroxine Assay. This EMIT thyroxine kit is particularly of interest for use in those clinical laboratories which have only a limited number of thyroxine determinations and/or do not have an expensive automatic analyzer. In this paper we present

(a) an evaluation of the EMIT Manual Thyroxine Assay with respect to precision, accuracy and specificity

(b) a comparison of results for patients' samples obtained with EMIT and $\mathrm{T}_{4}$ RIA-PEG (Abbott Laboratories) $)^{2}$ ).

1) EMITR, Syva Corp., Palo Alto, USA; Merckotest $R$, from E. Merck, Darmstadt for Europe.

2) $\mathrm{T}_{4}$ RIA (PEG); Abbott Laboratories, Diagnostic Division, North Chicago, USA.

\section{Materials and Methods}

Enzyme immunoassay (EMIT) of thyroxine

Reagents

EMIT Manual Thyroxine Assay Kit.

(Syva Corp., Palo Alto, USA; Merckotest, from E. Merck Darmstadt for Europe).

The reagents in the kit were accurately prepared and properly stored according to the manufacturer's instructions (11).

\section{Instruments and settings}

A Model $300 \mathrm{~T}$ spectrophotometer (Gilford, Oberlin, Ohio 44074), with digital readout was used to measure absorbances at $340 \mathrm{~nm}$. The spectrophotometer was connected to a Model 2400 Timer-Printer (Syva, Palo Alto, CA) for printing the absorbance reading at a precise time ( 9 seconds) after activation by the flow-cell sampling control.

The temperature of the flow cell was set at $25.0^{\circ} \mathrm{C}$. The sample volume was adjusted to $0.70 \mathrm{ml}$. Diluter dispensers from Syva were used for the addition of the various reagents.

A Model TX, thermostatic waterbath (Tamson, Zoetermeer, The Netherlands) was used for incubation of the samples at $37.00 \pm 0.05^{\circ} \mathrm{C}$. Eppendorf micropipettes of $50 \mu \mathrm{l}$ with disposable tips were used to deliver serum samples, thyroxine serum calibrators and the serum pretreatment solution. The assay was carried out in glass test tubes of $12 \times 75 \mathrm{~mm}$. A Genie Vortex mixer (Scientific Industries, Mineola, N.Y.) was used for mixing the content of each tube after the successive additions of the reagents. A timing device (Tamson, Zoetermeer, The Netherlands) was employed for the timing of the 15 second interval and the 15 minutes of incubation time.

\section{Procedure}

The determination of thyroxine with the EMIT Manual Thyroxine Assay Kit was performed according to the manufacturer's directions (11). Contrary to these directions, however, the contents of each tube were each time mixed separately after the successive additions of the various reagents, instead of vortexing a whole rack at once as recommended in the directions. This modification was used to prevent inadequate mixing of the components.

Radioimmunoassay (RIA) of thyroxine with use of polyethylene glycol (PEG) precipitation

\section{Reagents}

Test kit with ${ }^{125}$ I thyroxine.

( $\mathrm{T}_{4}$ RIA (PEG) Diagnostic Kit (Abbott Laboratories, Diagnostics Division, North Chicago, Il 60064, USA).

\section{Instrument and setting}

The radioactivity of the ${ }^{125}$ I thyroxine bound to the antiserum and from the ${ }^{125} I$ thyroxine solution in the total count tubes was counted in an automatic gamma counting system (Baird Atomic TRI-Gamma, The Hague, The Netherlands).

Time setting of the instrument was 1.20 minutes in which about 30,000 counts were obtained from the total count test tubes.

\section{Procedure}

The determination of thyroxine with the $\mathrm{T}_{4}$ RIA (PEG) kit was performed according to the manufacturer's instructions (12). In our procedure serum samples and standard were incubated with the antiserum for $2 \mathrm{~h}$ at room temperature $\left(22\right.$ to $\left.25^{\circ} \mathrm{C}\right)$

\section{Sample preparation}

Human sera were stored at $-20^{\circ} \mathrm{C}$ until used. Thyroxine-free serum was prepared by àdding $15 \mathrm{~g}$ of Dowex $50 \mathrm{~W}$ or Amberlite IRA 400 cation exchanger to $\mathbf{4 0 ~} \mathrm{ml}$ of serum. After mixing, the mixture was stored overnight at $4^{\circ} \mathrm{C}$. This treatment was repeated once. The removal of thyroxine (more than $99 \%$ by this procedure) was checked by addition of a trace amount of ${ }^{125} \mathrm{I}-\mathrm{T}_{4}$ to the serum before the procedure was started. Using this procedure no changes in the total protein content of the 
serum occurred; no differences were found in the electrophoretic pattern of the serum proteins and in the TBG content. A number of spiked serum samples with thyroxine concentrations of 40,80 , 120 and $200 \mu \mathrm{g} / 1$ respectively were prepared by diluting an aqueous stock solution of $2000 \mu \mathrm{g} / \mathrm{l} L$-thyroxine with thyroxinefree serum.

\section{Results}

\section{Standard curves}

In figure 1 a mean standard curve for the EMIT Manual Thyroxine method is presented. This curve is the average of 11 standard curves, which were run on several days during a 2 month time period. The calibrators used for the construction of these curves were from 6 kits with the same lot number. Figure 2 illustrates the mean standard curve $(n=5)$ for the $T_{4}$ RIA (PEG) method, which was obtained during the 2 months evaluation period for the EMIT kit. The mean fractions of ${ }^{125} \mathrm{I}-\mathrm{T}_{4}$ bound to

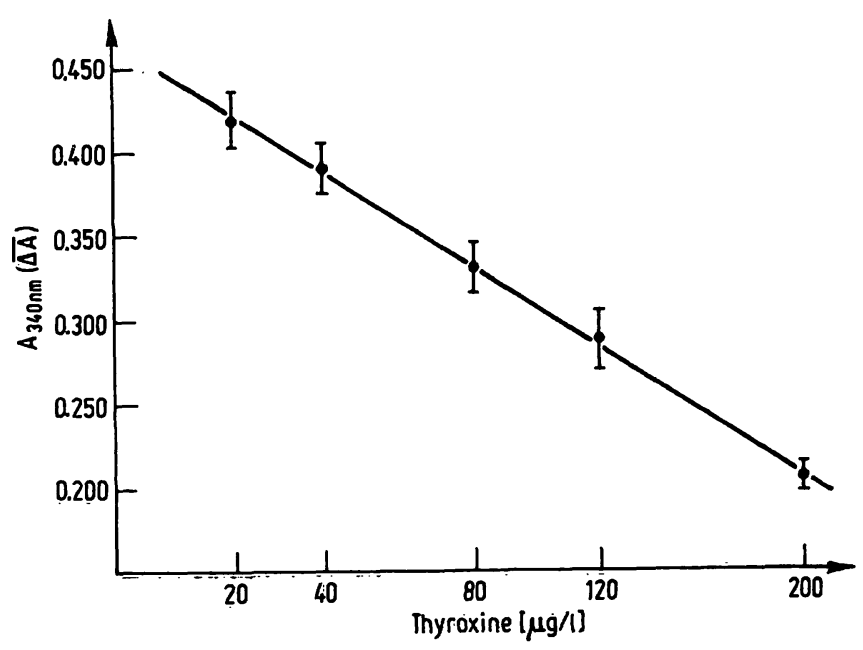

Fig. 1. Mean EMIT standard curve for thyroxine. Each closed circle is the average of 11 determinations. the antiserum for the 5 calibrators were plotted on the $\mathrm{Y}$-axis versus the calibrator concentrations on the $\mathrm{X}$-axis. The calibrators used for the construction of the curve were from 4 kits with the same lot number.

\section{Precision}

\section{Intra-Assay Precision}

The intra-assay variation of the EMIT Manual $\mathrm{T}_{4}$ Assay was determined by 10 replicate analyses of calibrators containing 40 and $120 \mu \mathrm{g} / \mathrm{l}$ of thyroxine. The coefficient of variation (CV) was $4.8 \%$ at a $\mathrm{T}_{4}$ level of $39.6 \pm$ $1.9 \mu \mathrm{g} / 1$ (mean $\pm \mathrm{SD})$ and $2.4 \%$ at $120.4 \pm 2.9 \mu \mathrm{g} / 1$.

\section{Inter-A ssay Precision}

The interassay (day-to-day) variation for both the EMIT and RIA $\mathrm{T}_{4}$ method was determined by calculating the coefficient of variation for each calibrator concentration from the mean standard curve of each me thod (figure 1 and 2). The mean value \pm SD of the absorbance (EMIT) or percentage bound radioactivity (RIA) of each calibrator was translated in to a thyroxine concentration and resulting coefficients of variation (CV\%) were plotted . versus the thyroxine calibrator concentrations in figure 3. Furthermore, the inter-assay variation was assessed by the replicate analysis of 5 patient samples of various thyroxine concentrations on 10 days during a 1 month period. The coefficient of variation was $50.0 \%$ at a $\mathrm{T}_{4}$ level of $8 \pm 4 \mu \mathrm{g} / \mathrm{l}$ (mean $\pm \mathrm{SD}$ ), $6.7 \%$ at $69 \pm 5,6.3 \%$ at $85 \pm 5,5.2 \%$ at $168 \pm 9$ and $4.1 \%$ at $232 \pm 10 \mu \mathrm{g} / \mathrm{l}$.

\section{Sensitivity}

The EMIT Manual Thyroxine Assay has been designed for optimum sensitivity in the assay range 20 to $200 \mu \mathrm{g} / \mathrm{l}$. Outside this range amounts of about $10 \mu \mathrm{g} / \mathrm{l}$ can be determined with a coefficient of variation of $\pm 50 \%$ and of $240 \mu \mathrm{g} / 1$ with a coefficient of variation of $5 \%$.

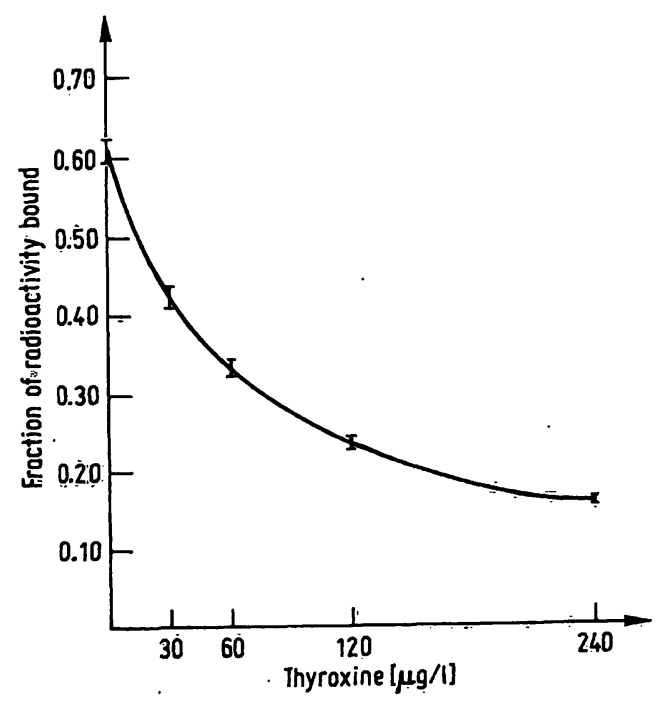

Fig. 2. Mean standard curve for thyroxine obtained with the $\mathbf{T}_{4}-$ RIA (PEG) method.

Each closed circle is the average of 10 determinations.

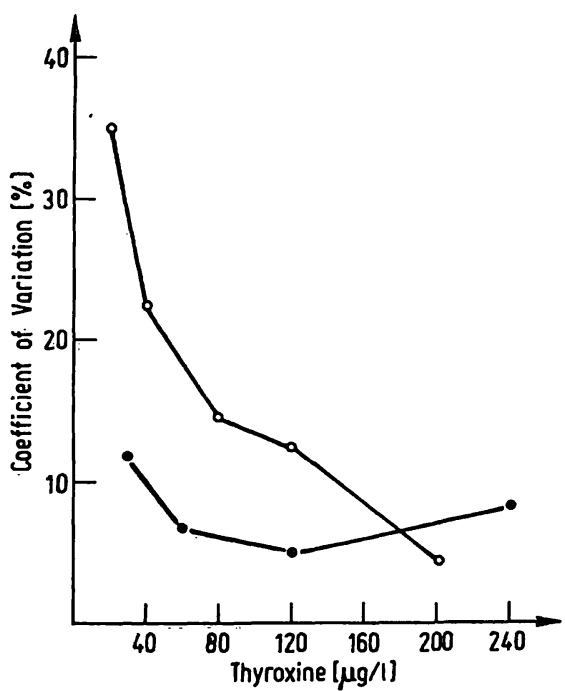

Fig. 3. Precision for the EMIT and $T_{4}$ RIA (PEG) method calculated from the mean standard curves. $\circ-0$, EMIT method; $\bullet-\bullet, T_{4}$ RIA (PEG) method. 


\section{Accuracy}

The results for the recovery of thyroxine by the EMIT and RIA method are shown in table 1. Thyroxine was added to thyroxine-free sera to give concentrations of $40,80,120$ and $200 \mu \mathrm{g} / 1$. The recovery at the various concentrations was adequate for both methods: $97-$ $107 \%$ with RIA and $91-103 \%$ with EMIT.

Tab. 1. Recoveries of thyroxine added to thyroxine-free serum.

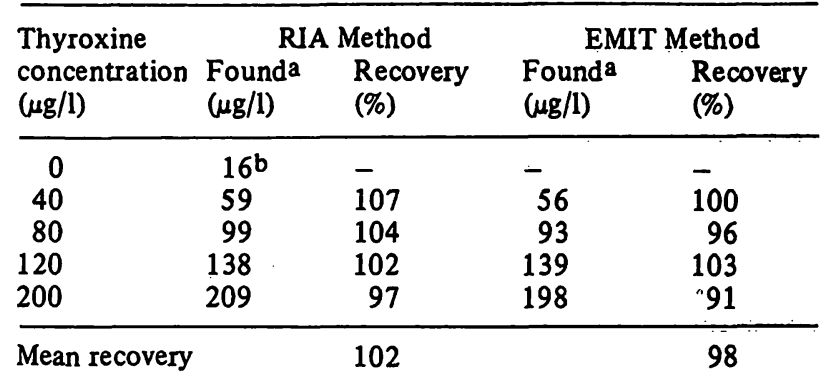

a) Each value is the mean of 7 analyses.

b) $\mathrm{T}_{4}$ concentration of thyroxine-free serum determined by RIA.

\section{Specificity}

The specificity of the EMIT and RIA method was tested by the determination of the cross-reactivity of compounds structurally related to thyroxine. Thyroxine-free sera containing $100 \mu \mathrm{g} / \mathrm{l}$ of each compound were prepared and subsequently measured by both methods. The apparent thyroxine content of each sample is summarized in table 2 together with the serum concentration range of each compound normally found in human serum.

\section{Comparison}

\section{Calibrators}

Five sets of EMIT thyroxine calibrators with the same lot number were analyzed with the RIA procedure and 5 sets of RIA calibrators were assayed with the EMIT method. The results of the analyses with both methods are presented in table 3 and 4 . The RIA analysis of the EMIT calibrators, as well as the EMIT analysis of the RIA calibrators, showed good agreement between the nominal stated and found concentrations. Deviations from the labeled values ranged from 0.1 to $5.1 \%$ for
Tab. 3. RIA analysis of EMIT Thyroxine calibrators.

\begin{tabular}{lll}
\hline $\begin{array}{l}\text { EMIT thyroxine } \\
\text { calibrator concen- } \\
\text { tration }\end{array}$ & $\begin{array}{l}\text { RIA assayed } \\
\text { values }\end{array}$ & Devlationb \\
$(\mu \mathrm{g} / \mathrm{l})$ & $(\mu \mathrm{g} / \mathrm{l})$ & $(\%)$ \\
\hline 20 & $20.2 \pm 2.4$ & +1.0 \\
40 & $41.4 \pm 3.3$ & +3.5 \\
80 & $80.1 \pm 2.9$ & +0.1 \\
120 & $125.8 \pm 8.0$ & +4.8 \\
200 & $210.1 \pm 19.8$ & +5.1 \\
\hline
\end{tabular}

a) Mean \pm SD of 12 determinations

b) Deviation from stated value in \%

Tab. 4. EMIT assay of RIA thyroxine calibrators.

\begin{tabular}{lll}
\hline $\begin{array}{l}\text { RIA thyroxine } \\
\text { calibrator concen- } \\
\text { tration }\end{array}$ & $\begin{array}{l}\text { EMIT assayed } \\
\text { value }^{\mathrm{a}}\end{array}$ & Deviationb \\
$(\mu \mathrm{g} / \mathrm{l})$ & $(\mu \mathrm{g} / \mathrm{l})$ & $(\%)$ \\
\hline 0 & $3.0 \pm 3.3$ & \\
30 & $31.0 \pm 4.7$ & +3.3 \\
60 & $61.6 \pm 5.2$ & +2.7 \\
120 & $119.6 \pm 9.2$ & -0.3 \\
240 & $214.0 \pm 9.2$ & -10.9 \\
\hline
\end{tabular}

a) Mean \pm SD of 9 determinations

b) Deviation from stated values in \%

the EMIT calibrators and from 0.3 to $10.9 \%$ for the RIA calibrators. The difference between the nominal stated and observed concentration for the RIA calibrator of $240 \mu \mathrm{g} / 1$ (table 4) is probably due to a lower sensitivity of the EMIT method in the determination of concentrations higher than $200 \mu \mathrm{g} / \mathrm{l}$. The difference in matrix of the RIA and EMIT calibrators (equine and human serum) showed no marked influence on the EMIT and RIA assayed values (table 3 and 4).

\section{Patient samples}

The results of a comparative evaluation of 100 patient's sera obtained with the EMIT and the RIA method are shown in figure 4. For the comparative study serum samples were selected with thyroxine concentrations ranging from $0-200 \mu \mathrm{g} / 1$. The analyses of specimens by

Tab. 2. Cross-reactivity of compounds related to thyroxine in the EMIT and RIA thyroxine assay.

\begin{tabular}{lllll}
\hline Compound & Concentration & Apparent thyroxine content in $(\mu \mathrm{g} / 1)^{\mathrm{a}}$ & $\begin{array}{l}\text { Normal range of serum } \\
\text { concentration } \\
(\mu \mathrm{g} / \mathrm{l})\end{array}$ \\
& $(\mu \mathrm{g} / \mathrm{l})$ & EMIT & RIA & - \\
\hline Thyroxine-free serum & - & - & 14 & $?$ \\
3-monoiodothyronine & 100 & 12 & 15 & 0.05 \\
3,5-diiodothyronine & 100 & 15 & 11 & $0.98-2.0$ \\
$3,3^{\prime}, 5$-triiodothyronine & 100 & 140 & 61 & 0.1 \\
$3,3^{\prime}, 5$-triiodothyroacetic acid & 100 & 17 & 15 & $0.75-2.9$ \\
$3,3^{\prime}, 5,5^{\prime}$-tetraiodothyroacetic acid & 100 & 170 & 82 &. \\
\hline
\end{tabular}

a) Each value is the mean of 4 determinations.

?) no reliable data available in the literature. 


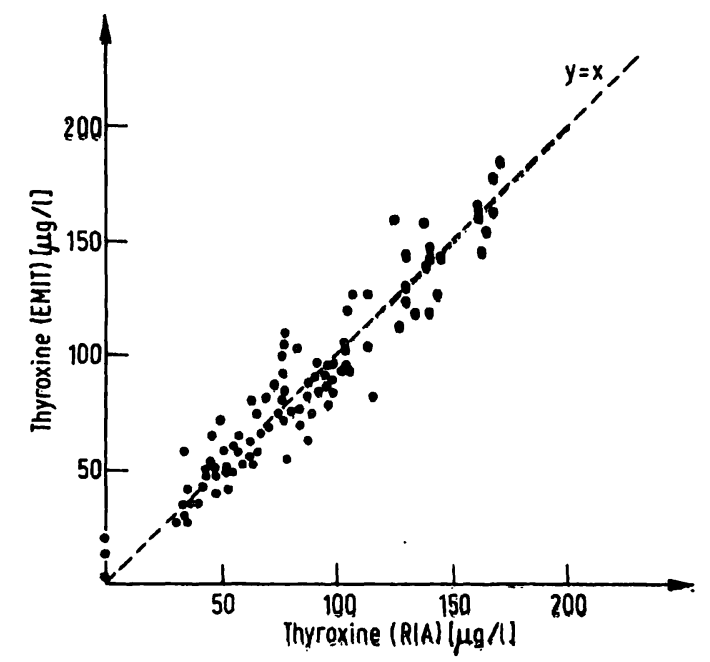

Fig: 4. Correlation between $T_{4}$ values as measured by the $T_{4}$ RIA method and by the EMIT method.

$$
\begin{aligned}
& y=0.96 x+3.37 \\
& r=0.955 \\
& n=100
\end{aligned}
$$

EMIT and RIA were performed in duplicate and the results were averaged, As none of these methods could be indioated as more aceurate, we calculated a regression line from an orthogonal instead of a linear regression analysis. This regression analysis of the paired data from 100 sera gave correlation coefficiont of 0.96 , a slope of 0.96 , and 8 y-intercept of $3.37 \mu \mathrm{g} / \mathrm{l}$. The mean value for thyroxine in the patient's sera was $88.1 \mu \mathrm{g} / \mathrm{l}$ for the BMIT method and $88.5 \mu \mathrm{g} / 1$ for the RIA method:

\section{Diagnosis of thyroid status}

The comparisons between the EMIT method and RIA method in the diagnestic elassification of 100 pationts, based on the normal ranges of $45=120 \mathrm{\mu g} /$ for EMIT (11) and $50=130 \mu \mathrm{g} / \mathrm{l}$ for the RIA assay (12), showed a diagnostic agreement in 89 out of the 100 patients. In addition, the difference of diagnosis (hypothyrootic by RIA and euthyreotie by BMIT) of 5 pationts was only caused by the variation of the low borderline values (45$50 \mu \mathrm{g} / \mathrm{t})$ of the nermal ranges of both methods.

\section{Diseusgion}

Ouf data in this study indieatet that the EMT Manual Thyrexine Assay when used exatly aceording to the

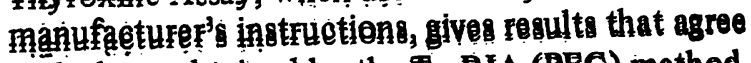
with these obtained by the Th RIA (PEG) mothod.

\section{Referenees}

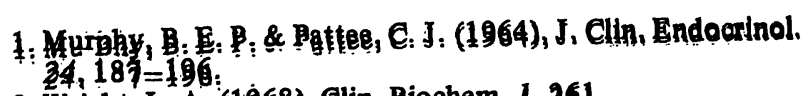

2. Wricht, A: (1968), Clin, Biechem. 1, 261.
Over a 2 month time period the variation in the mean standard curves, shown in figure 1 and 2, for both the EMIT and the RIA method was acceptable.

However, by plotting these standard deviations as coefficients of variation in the concentration versus the calibrator concentrations (fig. 3), it can be seen that especially the use of a mean EMIT standard curve for the calculation of the concentration of the samples is not acceptable. Therefore using the EMIT method for the thyroxine determination, it is essential to run a calibration curve each day of analysis. The intra-assay precision of the EMIT Method is satisfactory with a coefficient of variation ranging from $2.4-4.8 \%$. Except for the specimen with a $\mathrm{T}_{4}$ level of $8 \mu \mathrm{g} / 1$, which had a coefficient of variation of $50 \%$, the interassay variations in values obtained by EMIT for the same specimens were quite acceptable (coefficient of variation 4.1-6.7\%) during the 4 weeks in which this variable was measured. The analytical recovery for both methods was good and varied for EMIT from 91-103\% and for the RIA method from $97-107 \%$. Cross reactions for triiodothyronine and tetraiodothyroacetic acid were observed for the EMIT as well as the RIA assay. However from the levels normally found for the 2 compounds in human serum it can be concluded that they will have no clinically significant influence on the serum thyroxine concentration measured with both methods. From the good correlation $(r=0.955)$ between serum thyroxine concentrations obtained by the EMIT and RIA method it can be concluded that these assay techniques are equivalent. In addition, there was satisfactory agreement between the two methods in the diagnosis of the thyroid status. Thus, the EMIT Manual Thyroxine Assay is a good alternative for RIA methods and is especially suitable in hospital laboratories whlch may not have facilities for radioimmunoassay. Furthermore, compared to the $\mathrm{T}_{4}$ RIA (PEG) procedure, the EMIT Manual Thyroxine Assay has the advantage that the technique is simpler and faster and can be adapted more easily to automation. The total time of analysis of 40 unknown specimens in duplicate together with 5 calibrators in duplicate took about $4 \mathrm{~h}$ in the EMIT procedure and about $6 \mathrm{~h}$ in the RIA assay. For the reasons described in the introductory paragraphs and in the present study, we recommend the EMIT assay for analysis of serum thyroxine in the range of $20-200 \mu \mathrm{g} / 1$.

\section{Acknowledgements}

We wish particularly to thank Merck B.V. (Amsterdam, The Netherlands) for supplying the EMIT thyroxine kits. We are indebted to Mrs. Mariette Sprong for her technical assistance.
3. Chopra, I. J., Solomon, D. H. \& Ho, R. S. (1971), J. Clin. Endocrinol. 33, 865-866.

4. Chopra, İ. J. (1972), J. Clin. Endocrinol. 34; 938-947. 
5. Mitsuma, T., Colucci, J., Shenkman, L. \& Hollander, C. S. (1972), Biochem. Biophys. Res. Commun. 46, 2107-2113.

6. Ullman, E. F., Blakemore, J., Leute, R. K., Eimstad, W. \& Jaklitsch, A. (1975), Clin. Chem. 21, 1011.

7. Jaklitsch, A. P., Schneider, R. S., Johannes, R. J., Lavine,

J.E. \& Rosenberg, G. L. (1976), Clin. Chem. 22, 1185.

8. Galen, R. S. \& Forman, D. (1977), Clin. Chem. 23, 119-121.
9. Van Lente, F. \& Fink, D. J. (1978), Clin. Chem. 24, 387388.

10. Vogt, W., Tausch, A., Ebenroth, S. \& Dürmeijer, E. (1978), Freseñius Z. Anăl. Chem. 290, 97-98.

11. Syva instruction booklet fot EMIT Manual Thyroxine Assay. 12. Abbott instruction booklet for $T_{4}$ RIA (PEG) Diagnostic Kit.
Drs. T. A. Plomp

Centre for Human Toxicology

State University of Utrecht

Vondellaan 14

NL-3521 GE Utrecht

The Netherlands 